Abstracta Iranica Abstracta Iranica

Revue bibliographique pour le domaine irano-aryen

Volume 40-41 | 2019

Comptes rendus des publications de 2017-2018

\title{
Samra Azarnouche. « Cosmogonie et cosmologie zoroastriennes : l'état de Mélange (suite : Bundahišn 14 à 23) »
}

\section{Florence Somer}

\section{(2) OpenEdition Journals}

Édition électronique

URL : http://journals.openedition.org/abstractairanica/50812

DOI : $10.4000 /$ abstractairanica. 50812

ISBN : 1961-960X

ISSN : 1961-960X

Éditeur :

CNRS (UMR 7528 Mondes iraniens et indiens), Éditions de l'IFRI

\section{Référence électronique}

Florence Somer, «Samra Azarnouche. «Cosmogonie et cosmologie zoroastriennes : l'état de Mélange (suite : Bundahišn 14 à 23) » », Abstracta Iranica [En ligne], Volume 40-41 | 2019, document 6, mis en ligne le 30 décembre 2019, consulté le 17 avril 2021. URL : http://journals.openedition.org/ abstractairanica/50812 ; DOI : https://doi.org/10.4000/abstractairanica.50812

Ce document a été généré automatiquement le 17 avril 2021

Tous droits réservés 


\section{Samra Azarnouche. « Cosmogonie et cosmologie zoroastriennes : l'état de Mélange (suite : Bundahišn 14 à 23)»}

Florence Somer

\section{RÉFÉRENCE}

Samra Azarnouche. «Cosmogonie et cosmologie zoroastriennes : l'état de Mélange (suite : Bundahišn 14 à 23) ", Annuaire de l'EPHE, section des Sciences religieuses, $\mathrm{n}^{\circ} 125$, résumés des conférences (année 2016-2017) 2018, p. 231-239 : https://

journals.openedition.org/asr/1975

1 Ces conférences, basées sur un travail de traduction et de recherche en chantier, mettent en lumière la structure globale du Bundahišn et l'articulation de ses chapitres en analysant les éléments contenus dans les chapitres 24 à 36 de ce traité. Bien qu'il se constitue autour des trois phases de la chronologique mythique iranienne- création, état de mélange, séparation- c'est le second état qui occupe particulièrement le rédacteur. Indubitablement rattaché à la tradition exégétique et à son substrat avestique, le Bundahišn n'est pourtant pas un traité ritualiste mais se concentre avec attention sur les sciences naturelles, le réel et l'interdépendance entre l'homme et son environnement. 


\section{AUTEURS}

\section{FLORENCE SOMER}

Doctorante EPHE, Mondes iranien et indien, Paris 